\title{
Anabolic Steroids Effects on Bone Regeneration
}

\author{
José Carlos Pansieri, Alessandra Esteves, Wagner Costa Rossi Junior* \\ Institute of Biomedical Sciences, Department of Anatomy, Federal University of Alfenas, Alfenas, Brazil \\ Email address: \\ wcrj@unifal-mg.edu.br(W. C. R. Junior),wagnerunifal@gmail.com (W. C. R. Junior) \\ ${ }^{*}$ Corresponding author
}

\section{To cite this article:}

José Carlos Pansieri, Alessandra Esteves, Wagner Costa Rossi Junior. Anabolic Steroids Effects on Bone Regeneration. American Journal of Sports Science. Vol. 7, No. 2, 2019, pp. 88-93. doi: 10.11648/j.ajss.20190703.12

Received: June 9, 2019; Accepted: July 16, 2019; Published: July 30, 2019

\begin{abstract}
In recent decades, the importance given to body appearance has grown dramatically, as has the consumption of socalled "body image drugs," which include androgenic anabolic steroids (AAS), synthetic substances derived from testosterone. Although the therapeutic use of anabolic steroids are beneficial and necessary to body when there is reduction or depletion of these substances, the excessive use is related to negative interference in fracture healing process. Thus, the objective of study was to verify if there is influence of AAS in process of bone repair. For this, twenty Wistar rats were used, in which a fracture with bone loss was performed on left fibular diaphysis. Subsequently, they were divided into four groups and the animals were treated for one (1) month, with physiological solution $(0.02 \mathrm{ml})$, Durateston ${ }^{\circledR}(83.3 \mathrm{mg} / \mathrm{kg}[0.02 \mathrm{ml}])$ and Deca Durabolin ${ }^{\circledR}$ $(16.6 \mathrm{mg} / \mathrm{kg}[0.02 \mathrm{ml}])$, applied once a week. The results showed that there was a significant loss in bone healing on groups treated with AAS, since there was no regeneration in fractured fibula, besides increasing resorption process at the ends of fracture stumps. For this reason it is possible to conclude that the misuse of AAS interferes negatively in metabolism of bone tissue reinforcing the danger of indiscriminate use for health, warning that, addition other biological tissues, the bone may be affected by abuse of these substances.
\end{abstract}

Keywords: Anabolic Steroids, Testosterone, Fracture Fibula, Bone Regeneration

\section{Introduction}

The bone fracture healing is one of the most interesting repair processes that occurs in nature, not only by formation of a scar, but total reconstitution of injured tissues, which can resume their original form. Although regeneration of bone tissue is a well-defined process, complications inherent in treatment of fractures and bone defects are still observed, since some factors are not fully elucidated or conclusive [13]. One of these factors, for which there is still no complete knowledge in formation and maintenance of bone tissue is androgenic anabolic steroids (AAS).

From 1976, at Montreal Olympics, control of AAS began, where six athletes were punished for use of these substances [4]. This control occurred for ethical reasons and because of harmful effects on health. Since then, these substances have been banned by International Olympic Committee [5]. Although not detectable until 1975, since 1950s the AAS are administered to increase strength and improve physical endurance [6].
In synthesis of AASs, known modifications occur in testosterone molecule as 17-position alkylation and/or modification of ring structure. These modifications are made to produce derivatives with more anabolic and less androgenic characteristics than original molecule. The esterification of hydroxyl group with carboxylic acids also increases the activity of steroids, as it causes an increase in action by obtaining lipophilic properties and, therefore, retention in adipose tissue. AAS perform their functions through binding to the androgen receptor [7]. There are two mechanisms of testosterone action, direct and indirect mechanism. The direct mechanism is mediated by interaction of hormone with the androgen receptor, which is found in cytoplasm. After interaction and translocation to specific regions of nucleus, signaling to protein synthesis occurs. The indirect mechanism does not depend on testosteroneandrogen receptor interaction, but on interaction with other trophic factors, and also on the interaction of AAS with the glucocorticoid receptor, which acts to inhibit protein degradation [8].

AAS have more recently been considered for antiaging 
therapy in males because testosterone would act to improve the physical and emotional disposition of patients, demonstrating a regenerative effect. In case of polytrauma and burns, this same reasoning is used, since the AAS accelerates the time of onset of scar [9].

The androgens action mechanism in male cortical and trabecular bone was investigated using rodent models. The most important effect was inducement periosteal bone formation and cortical bone expansion, which have important bone strengthening benefits. Pre- and post-pubertal deletion of androgen receptors impairs cortical and trabecular bone mass in male mice; however, the effect of inducible deletion in adult or elderly mice continues to be investigated and the target genes for effect of androgens on periosteal bone formation are still unknown [10].

Hedström [11] suggest that a low dose of nandrolone decanoate, in combination with a low dose of alfacalcidol and calcium, have a positive effect on body composition, bone mineral density and clinical function of elderly women after hip fracture. However, for Farooki [12], the available evidence for anabolic steroids action after surgical treatment of hip fracture in older people is insufficient to draw conclusions about its effects, mainly in terms of functional outcome and adverse events, using alone or in combination with nutritional supplements.

In recent decades, the importance given to body appearance has grown dramatically. The emergence of new techniques of care and improvements of body and the socalled "body image drugs", which include AAS, has also increased in recent years [13]. So, the objective of this study was to analyze the repair of surgically created bone defects in rats fibulae and to verify the interference and possible effects of anabolic steroids in repair process, in order to support their use as a resource treatment of fractures.

\section{Material and Methods}

Twenty male Wistar rats (Rattus norvegicus) from Bioterium of Federal University of Alfenas, UNIFAL-MG, were housed in boxes containing two animals each, treated with commercial feed and water ad libitum and kept in a cycle of 12 light-dark hours. The research was submitted and approved by Ethics Committee on use of Animals in Federal University of Alfenas, with protocol number 662/2015.

The animals were divided into four (4) experimental groups $(\mathrm{n}=5)$ : group I - animals treated with sterile physiological solution; group II - animals treated with the anabolic Deca Durabolin ${ }^{\circledR}$ 50mg (Schering-Plough, São Paulo, São Paulo, Brazil); group III - animals treated with anabolic steroid Durateston ${ }^{\circledR}$ (Schering-Plough, São Paulo, São Paulo, Brazil); group IV - animals treated with the two anabolic agents, Deca Durabolin $\AA$ and Durateston $\AA$. The treatment consisted in application of two anabolic steroids, the first, nandrolone decanoate marketed under the name Deca Durabolin ${ }^{\circledR}$ and the second an association of testosterone propionate, testosterone fenpropionate, testosterone isocaproate and testosterone decanoate marketed under the name of Durateston ${ }^{\circledR}$. The animals were treated for one (1) month, the doses of $0.02 \mathrm{ml}$ physiological solution being that of Durateston ${ }^{\circledR} 83.3 \mathrm{mg} / \mathrm{kg}(0.02 \mathrm{ml})$ and the doses of Deca Durabolin ${ }^{\circledR} 16.6 \mathrm{mg} / \mathrm{kg}(0.02 \mathrm{ml})$ applied once a week [14-18].

For surgical removal of fibular fragments, the animals were anesthetized through intraperitoneal injection with a mixture of ketamine hydrochloride (Ketalex ${ }^{\circledR}-50 \mathrm{mg} / \mathrm{ml}$ ) (Rhabi, Hortolândia, São Paulo, Brazil) and xylazine hydrochloride (Sedalex ${ }^{\circledR}-2 \mathrm{~g} / 100 \mathrm{ml}$ ) (Rhabi, Hortolândia, São Paulo, Brazil) at a dose of $0.20 \mathrm{ml} / 100 \mathrm{~g}$ and $0.10 \mathrm{ml} / \mathrm{kg}$, respectively. Then, at surgery site, trichotomy and asepsis were performed. An incision was made on lateral side in left leg of animal. The subcutaneous tissues were removed for visualization of fascial plane. The muscle fascia was incised and the muscles were carefully keep away for exposure of fibula. In the middle third of diaphysis, a bone fragment of 1.5 to 2 millimeters was removed (figure 1), measured with the aid of a millimeter endodontic ruler. Immediately after surgery, the animals received a dose of dipyrone $(50 \mathrm{mg} / \mathrm{kg})$; intraperitoneally. The tissues were repositioned and sutured.

The study represents a completely randomized design (CRD), therefore, the statistical analysis was performed through an analysis of variance (One-Way ANOVA) followed by Tukey averages comparison test, values of $\mathrm{p}<0.05$ were considered as indicative of significance.

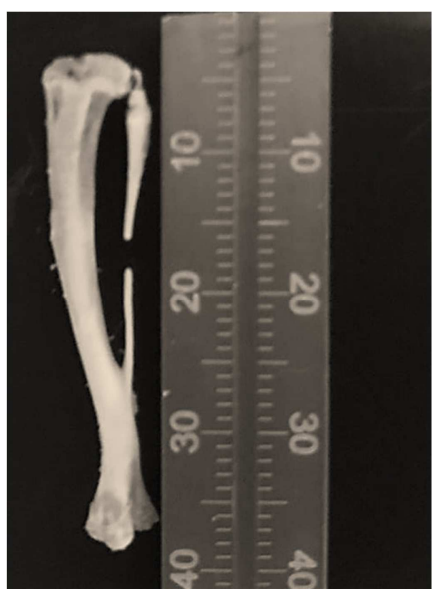

Figure 1. Fibulae with bone defect.

\section{Results}

The results obtained in this study show that the use of anabolic steroids Deca Durabolin ${ }^{\circledR}$ and Durateston ${ }^{\circledR}$ was harmful in process of bone regeneration. The radiographic analysis showed that the animals of group I, that is, those that were not treated with anabolic steroids had the process of bone regeneration fully effective. The same could not be observed for any of other three groups evaluated. Figure 2 shows the radiographic appearance forty days after surgery. The analysis was made through the existence or not of radiopacity between the stumps or fragments of fracture. 


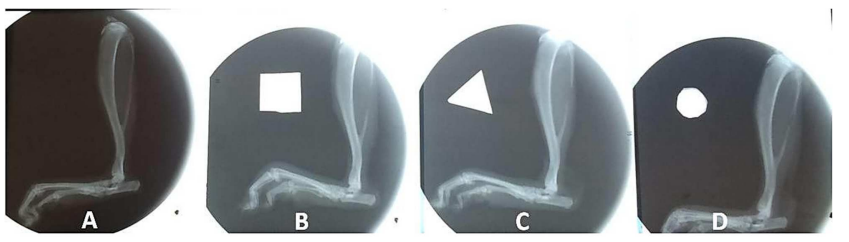

Figure 2. Radiographic appearance of fractured fibulas 40 days after surgery. A- Group I; B - Group IV; C - Group II; D - Group III. *Square, triangle and circle were used to separate the groups.

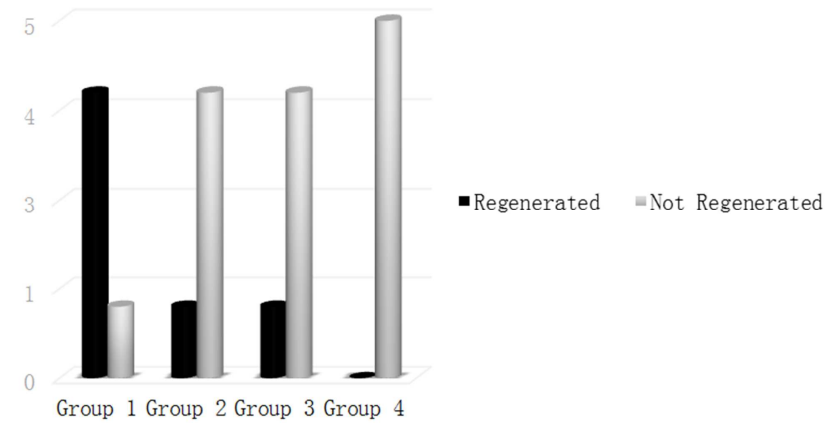

Figure 3. Animals that presented regeneration or not, after 40 days of creation of a bone defect in fibulae.

It can be visualized by figure 2 that in group 1 there is union (radiopacity) between the ends of fracture, indicating radiographic bone regeneration. In other groups analyzed, it was not possible to observe a radiopaque area between the fracture ends. Contrarywise, a process of resorption may be perceived, especially in distal stump, since the ends of fracture are far away. It is also observed that the group as received the two anabolic agents (B-Group IV) presented a higher degree of resorption in relation to other two groups that received only one of two steroids evaluated.

Figure 3 shows the numerical values related to regeneration process radiographically analyzed. It is quite clear that the steroids and doses used in this experiment have disadvantaged the process of bone regeneration.

The histological analysis corroborates with the radiographic results, that is, the animals treated with anabolic steroids of this experiment did not present regeneration or any signal that showed than process was occurring. In inner of bone defects, only fibrous connective tissue and surrounding muscle cells entering the defect were visualized. There was distancing between the fracture stumps, indicating reabsorption of extremities and favoring the entrance of adjacent muscles in bone defect center, which naturally contributed to non attendence bone regeneration of region. Figure 4 (letter A and B) exemplifies an animal from group III, which received an anabolic steroid, as well as the other two groups that were also treated with this substance. Note that in area of bone defect, what predominates are muscle cells that invaded the region. Figure 4 (letters C) shows the histological appearance of group I animal, where it is clearly perceived the formation of new bone tissue in surgically created defect.
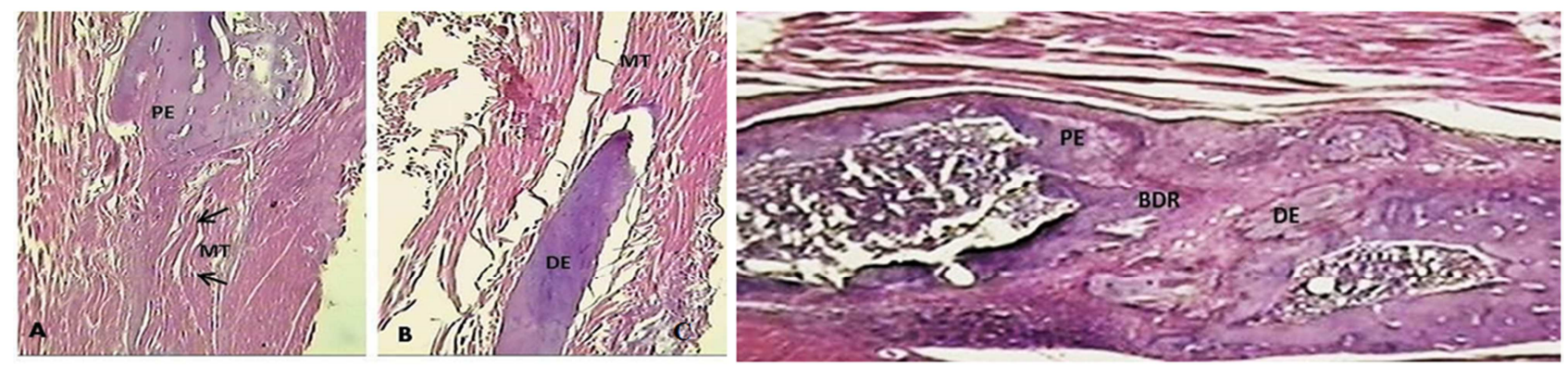

Figure 4. A and B-Histological appearance of fibulae in unregenerate animal (group III). A- proximal region of bone defect; PE- proximal end; MT- muscle tissue (arrows show muscle tissue invading the bone defect); B- distal region of bone defect; DE- distal end; MT- muscle tissue. C-Fibulae histological aspect in animal of group I. PE- Proximal end; BDR- bone defect regenerated; DE-Distal end. Staining used: HE. $20 x$ magnification.

\section{Discussion}

Experimental studies in rat fibulae have shown that, fractures with bone loss present spontaneous regeneration in defects of non-critical size, i.e., less than or equal to $2.5 \mathrm{~mm}$. [19]. However, defects of great extent or critical size (greater than $2.5 \mathrm{~mm}$ ) do not allow spontaneous reconstitution, being necessary to implantation of membranes or other barrier materials or even fragments of periosteum inducing the regeneration process. It is also important to point out that the place where defect is produced is extremely relevant. The bone marrow in rats fibulae is found especially in proximal and middle thirds, while in the distal region it is almost nonexistent. For this reason, in this experiment, bone defects were performed in media region of fibulae diaphysis, containing bone marrow, so that the regeneration process could occur within normality patterns [20].

In the year 1889, the investigator Brown-Séquard injected into himself an extract prepared from testicles of dogs and india pigs. He reported that he felt a boost in vitality [21]. Several decades later, in 1930, testosterone was isolated and characterized, and its name was used for first time in Germany. Testis interstitial cells promote the synthesis of testosterone, which plays an important role in spermatogenesis, development of secondary sexual characteristics, release of gonadotrophins and stimulation of protein synthesis [22]. In 1950s, testosterone was used orally and injected as treatment in some types of anemia, in diseases with muscle loss and in post-surgical patients, in order to reduce secondary muscle atrophy [23].

The main androgen secreted in men is testosterone. Its secretion occurs from cholesterol molecule and the central 
stimulus of hypothalamic-pituitary axis. The hypothalamus secretes Gonadotropin-Releasing Hormone, which in turn stimulates the pituitary to secrete luteinizing hormone, which acts on testis interstitial cells. After its secretion, the testosterone can act directly in target cells or undergo metabolization, originating inactive compounds and active, ones as dihydrotestosterona. The reaction that gives rise to dihydrotestosterone is catalyzed by enzyme $5 \alpha$-reductase. And the reaction which gives rise to estradiol, is catalyzed by enzymatic complex aromatase (CYP19). Testosterone may act directly on cells, binding to androgen receptor, or via dihydrotestosterone, which binds most avidly to this receptor [24].

In this experiment two anabolic steroids were used. Durateston ${ }^{\circledR}$, which has four esters with different durations of action, which are hydrolyzed in bloodstream, resulting in natural hormone testosterone. A single dose of Durateston increases total plasma testosterone 24 to 48 hours after dosing, and levels return to normal within men within 21 days. The other steroid used was Deca-Durabolin ${ }^{\circledR}$, which has nandrolone decanoate ester that provides action duration of about three weeks after administration; in bloodstream it is hydrolyzed into nandrolone. Compared with testosterone, nandrolone shows increased anabolic activity and reduced androgenic activity [25].

In this experiment, no regeneration of defects surgically created in rats fibula was observed. These results contrast with Sant'Anna [19], which establishes that defects up to 2.5 $\mathrm{mm}$. has spontaneous regeneration. In this case, it is possible that steroids used interfered negatively, impeding it from regeneration occurring, favoring the process of osteoclastic reabsorption. In this sense, the results of this study contradict too Hedström [11], who state that low doses of anabolic steroids contribute positively to bone mineral density, although all animals in this study received supraphysiological doses in a short period of time, which was probably the factor that prevented the process of bone regeneration.

Laurent [10] report beneficial effects of testosterone in older hypogonadal men, especially trabecular bone, provided that they are therapeutically used, i.e., with low doses, sufficient for replacement. The data from this study make it clear that indiscriminate use, with excessive doses, can hinder and impede the repair and regeneration of lesions or bone fractures. In this sense, it would be very interesting that each health professional responsible for surgical interventions involving bone tissue (orthopedic surgeons, dental surgeons etc.) have knowledge whether or not the patient uses these substances and how much and how long these drugs have been used, so that no undesired event occurs during the patient recovery process.

According to Ribeiro [26] androgenic anabolic steroids also promote placebo, psychological, euphoric, anticatabolic, decrease fatigue and improve protein synthesis. In addition, Silva [27] reported increased muscle mass, increased hemoglobin and hematocrit concentration, nitrogen retention, increased calcium deposition in bones and increased fat burning, which causes athletes to use such drugs in order to improve performance. However, the results of this study show that supraphysiological doses interfere with bone metabolism, perhaps due to increased osteoclastic function and reduction of osteoblastic function.

Anabolic steroids, when used in supraphysiological doses, have effects on thyroid gland function. Among these effects, the most pronounced in humans is decrease in TBG (thyroxine binding Globulin). As this protein is responsible for maintenance of $\mathrm{T} 3$ and $\mathrm{T} 4$ serum concentrations for the cellular use and consequent biological response, its reduction decreases the total serum concentration of these hormones. However, this decrease will depend on susceptibility to aromatization of anabolic steroid used. A number of other alterations have also been reported in humans, and most studies have shown the appearance of a condition that may be confused with subclinical hypothyroidism, with elevated serum TSH (thyroid stimulating hormone) and normal free T4 [28-32]. Our data corroborate and are supported by these results, since the metabolism of bone tissue is directly influenced by thyroid hormones. Thus, as there is reduction of TBG when using supraphysiological doses of anabolic steroids, it is expected that there will be a reduction in rate of bone remodeling and loss of this tissue, results observed and proven in this experiment.

Although the experiment does not show the action mechanism of steroids in bone tissue, it is evident that the indiscriminate use, in excessive doses, interferes negatively in consolidation of fractures with bone loss and, naturally, when using these drugs, should be carried out safely, since whole organism can be affected, positively or not. Thus, new studies should be performed, seeking to prove the real participation of anabolic steroids in bone formation and regeneration, so that the use is made in a totally safe and with appropriate therapeutic indications. The results obtained reinforce the danger of indiscriminate use for health, demonstrating that, addition to other biological tissues already reported in literature, the bone may be affected by use of these substances.

\section{Conclusion}

The results obtained in this study, which analyzed the effects of supraphysiological doses of anabolic steroids nandrolone decanoate and the association of testosterone propionate, testosterone fenpropionate, testosterone isocaproate and testosterone decanoate allow to conclude that there is a negative influence on the bone regeneration process in rats fibular fractures with bone loss, since the regeneration process did not occur in treated animal, besides increasing resorption process at the ends of fracture stumps. Thus, as use of anabolic steroids has increased and is increasing today, new studies and different biological tissues must be performed to show that, when used improperly, they are extremely dangerous and harmful substances that should be administered only in cases where the cost-benefit ratio is quite considerable. 


\section{Conflict of Interest}

The authors declare that they have no conflict of interest.

\section{References}

[1] S. Oryan, A. Monazzah, A. Bigham-Sadegh. Bone Injury and Fracture Healing Biology. Biomed Environ Sci, 2015; 28 (1): 57-71. doi: 10.3967/bes2015.006.

[2] J. G. M. P. Isola, P. C. Moraes. Estrutura e regeneração óssea revisão de literatura. Revista Científica Eletrônica de Medicina Veterinária, 18 (2012).

[3] L. C. Junqueira, J. Carneiro. Histologia Básica. 12.ed. Rio de Janeiro: Guanabara Koogan, 2013.

[4] T. S. Cunha, A. P. Tanno, F. K. Marcondes, S. E. A. Perez. A administração de nandrolona não promove hipertrofia do músculo sóleo em ratos. Arq Bras Endocrinol Metab, 50 (2006): 532-540. doi: 10.1590/S0004-27302006000300017.

[5] M. A. S. Marques, H. M. G. Pereira, F. R. Aquino Neto. Controle de dopagem de anabolizantes: o perfil esteroidal e suas regulações. Bras Med Esporte, 9 (2003): 15-24. http://dx.doi.org/10.1590/S1517-86922003000100004.

[6] F. C. Cruz, S. A. Engi, R. M. Leão, C. S. Planeta, C. C. Crestani. Influence of the single or combined administration of cocaine and testosterone in autonomic and neuroendocrine responses to acutere straint stress. J. Psychopharmacol, 26 (2012): 1366-74. doi: 10.1177/0269881112453210.

[7] A. G. Fragkaki, Y. S. Angelis, M. Koupparis, A. TsantiliKakoulidou, G. Kokotos, C. Georgakopoulos. Structural characteristics of anabolic androgenic steroids contributing to binding to the androgen receptor and to their anabolic andandrogenic activities applied modifications in the steroidal structure. Rev Steroids, 74 (2009): 172-197. doi: 10.1016/j.steroids.2008.10.016.

[8] P. D. Venâncio. Esteroides anabolizantes e seu efeito sobre as variáveis bioquímicas e neuroendócrinas em indivíduos que praticam exercício resistido. Revista Brasileira de Medicina do Esporte, 16 (2010): 191-195. doi: 10.1590/S151786922010000300007 .

[9] F. Cecchetto, D. R. Moraes, P. S. Farias. Distintos enfoques sobre esteroides anabolizantes: riscos à saúde e hipermasculinidade. Interface-Comunicação, Saúde, Educação, 16 (2012): 369-82. http://dx.doi.org/10.1590/S141432832012005000008 .

[10] M. R. Laurent, L. Dedeyne, J. Dupont, B. Mellaerts, M. Dejaeger, E. Gielen. Age-related bone loss and sarcopenia in men. Maturitas, 122 (2019): 51-56. https://doi.org/10.1016/j.maturitas.2019.01.006

[11] M. Hedström, K. Sjöberg, E. Brosjö, K. Åström, H. Sjöberg, N. Dalén. Positive effects of anabolic steroids, vitamin D and calcium on muscle mass, bone mineral density and clinical function after a hip fracture. A randomised study of 63 women. J Bone Joint Surg, 84 (2002): 497-503.

[12] V. Farooqi, M. E. Van Den Berg, I. D. Cameron, M. Crotty. Anabolic steroids for rehabilitation after hip fracture in older people. Cochrane Database Syst Ver, 10 (2014): 467-468. http://dx.doi.org/10.1590/1516-3180.20161345t2
[13] J. A. B. Iriart, J. C. Chaves, R. G. Orlean. Culto ao corpo e uso de anabolizantes entre praticantes de musculação. Cad. Saúde $\quad$ Pública, 25 (2009): 773-782. http://dx.doi.org/10.1590/S0102-311X2009000400008

[14] A. T. Kicman. Pharmacology of anabolic steroids. British Journal of Pharmacology, 154 (2008): 502-521. doi: 10.1038/bjp.2008.165.

[15] R. C. Agis-Balboa, N. Maria, F. Pibiri, G. Pinna. Enhanced fear responses in mice treated with anabolic androgenic steroids. Neuroreport, 20 (2009): 617-21. doi: 10.1097/WNR.0b013e32832a2393.

[16] J. Corrêa, V. Amorin, D. A. Nogueira, E. A. Soares, F. R. Guerra, G. J. M. Fernandes, W. C. Rossi Junior, A. Esteves. Neuronal quantification in mice cerebral cortex under use of Ayahuasca tea. Revista Neurociências, 22 (2014): 388-391. DOI: 10.4181/RNC.2014.22.03.933.4p.

[17] C. Ribeiro, D. K. Silva, B. Damião, D. M. Alves, A. Freitas, W. C. Rossi Junior, A. Esteves. Quantitative analysis of mices purkinje cells under the use by anabolic steroids. Revista Neurociências, $22 \quad$ (2014): 432-437. DOI: 10.4181/RNC.2014.22.03.969.6p

[18] A. C. Freitas, B. Damião, D. M. Alves, M. Ribeiro, G. J. M. Fernandes, W. C. Rossi Junior, A. Esteves. Effects of anabolic agents on the neuron density of the basal nuclei. Rev Bras Med Esporte, 23 (2017): 213-216. doi: 10.1590/1517869220172303151688 .

[19] M. F. Sant'anna. Capacidade osteogênica de enxertos periosteais livres. [Tese]. Universidade Estadual Paulista (UNESP). 1997.

[20] W. C. Rossi Junior. Influência de uma membrana de colágeno associada a extrato etanólico de própolis na consolidação de fraturas com perda óssea. [Tese]. Faculdade de Odontologia de Piracicaba - Universidade Estadual de Campinas (UNICAMP). 2002.

[21] G. Kanayama, J. I. Hudson, H. G. Pope Jr. Illicit Anabolic Androgenic Steroid Use. Horm Behav, 58 (2010): 111-121. doi: 10.1016/j.yhbeh.2009.09.006

[22] E. Tasgin, S. Lok, N. Demir. Combined usage of testosterone and nandrolone may cause heart damage. African Journal of Biotechnology, $10 \quad$ (2011): 3766-3768. DOI: 10.5897/AJB10.2714

[23] M. D. C. Dandoy, R. S. M. D. Gereige. Performanceenhancing drugs. Pediatr Rev, 33 (2012): 265-272. doi: 10.1542/pir.33-6-265.

[24] B. Laurence, K. Björn, H. D. Rande. Goodman \& Gilman's the pharmacological basis of therapeutics. 13. ed. New York: McGraw Hill Medical, 2018.

[25] DEF Dicionário de especialidades farmacêuticas. $42^{\mathrm{a}}$ edição, Editora EPUC, 2014.

[26] P. C. P. Ribeiro. The substances abuse: anabolizant steroids and energy drugs. Adolesc. Latinoam, 2 (2001): 97-101.

[27] P. R. P. Silva, R. Danielski, M. A. Czepielewski. Esteroides anabolizantes no esporte. Rev. Bras. Med. Esporte, 8 (2002): 235-243. http://dx.doi.org/10.1590/S151786922002000600005 
[28] F. C. W. Wu. Endocrine aspects of anabolic steroids. Clin. Chem, 43 (1997): 1289-92.

[29] R. S. Fortunato; D. Rosenthal; D. P. De Carvalho. Abuso de Esteroides Anabolizantes e seu Impacto sobre a Função Tireóidea. Arq Bras Endocrinol Metab 2007; 51/9:1417-1424. Doi.org/10.1590/S0004-27302007000900003.

[30] S. K. Banu, J. A. Arosh, P. Govingarajulu, M. M. Aruldhas. Testosterone and estradiol differentially regulate thyroid growth in wistar rats from immature to adult age. Endocr Res, 27 (2001): 447-63.
[31] R. C. Daly, T. P. Su, P. J. Schmidt, M. Pagliaro, D. Pickar, D. R. Rubinow. Neuroendocrine and behavioral effects of high dose anabolis steroid administration in male normal volunteers. Psychoneuroendocrinology, 28 (2003): 317-331.

[32] S. O. Abde-Allh, S. A. Rahim. Anabolic Androgenic Steroid in male adult mice induced: Hypothyroidism, Oxidative stress. Euphrates Journal of Agriculture Science, 2014; 6 (4): 16-29. 